CZASOPISMO INŻYNIERII LADDOWEJ, ŚRODOWISKA I ARCHITEKTURY JOURNAL OF CIVIL ENGINEERING, ENVIRONMENT AND ARCHITECTURE JCEEA, t. XXXII, z. 62 (4/15), październik-grudzień 2015, s. 195-200

\author{
Peter KAPALO ${ }^{1}$ \\ Anna SEDLAKOVA ${ }^{2}$ \\ Orest VOZNYAK ${ }^{3}$ \\ Ladislav TAZKY ${ }^{4}$
}

\title{
REQUIREMENT TO THE FRESH AIR IN THE CONGREGATION ROOM
}

\begin{abstract}
We have more kinds of congregation rooms. When building of these spaces must to supervise, among other the requirements also the quality of the indoor air should be considered. In our article we are engaged analysis of ventilation in church of the 13th century. The aim is analyzing of produce of pollutant emissions from persons in the room. One of measurable the pollutant is carbon dioxide, which is produced by persons. Beside the respiration, the person produces other pollutants, such as odor and others. On the basis of experimental measurements the concentration of carbon dioxide produced by person, currently we know calculate how much air exchange is required for the room. The concentration of carbon dioxide has be smaller how 1,000 ppm and maximum up to 1,500 ppm. Already above the value of $1,000 \mathrm{ppm}$ causes to decrease the concentration to perception for people. The aim of the paper is to determine the methodology for calculating the intensity of ventilation rate in the room. It is need to maintain the required air quality. Calculated ventilation rate should optimize investment and operating costs of ventilation equipment. In the work there is carried out analysis of calculation methods to determine the ventilation rate. It is processed the methodology for calculating the ventilation rate of room, there are used the measured values of concentrations of carbon dioxide. Values of concentrations of carbon dioxide and ventilation rate there are verified by experimental measurements. The methodology is selected for calculating ventilation rate applicable in to Slovakia.
\end{abstract}

Keywords: ventilation, concentration of carbon dioxide, mass flow rate, room.

\footnotetext{
${ }^{1}$ Author for correspondence: Peter Kapalo, Institute of Architectural Engineering. Civil Engineering Faculty, TU of Kosice. Vysokoškolská 4. 04200 Košice. Slovakia, +421 55602 4271, peter.kapalo@tuke.sk.

2 Anna Sedlakova, Institute of Architectural Engineering. Civil Engineering Faculty, TU of Kosice. Vysokoškolská 4, 04200 Košice. Slovakia, +421 55602 4165, anna.sedlakova@tuke.sk.

3 Orest Voznyak, Heat, Department of Gas Supply and Ventilation, National University "Lviv Polytechnic”, Bandery Str.12, 79013 Lviv, Ukraine, tel: +380 322 582784, orest.voznyak@i.ua

${ }^{4}$ Ladislav Ťažký, Eng, Institute of Architectural Engineering. Civil Engineering Faculty. TU of Kosice. Vysokoškolská 4, Košice. Slovakia, ladislav.tazky@tuke.sk.
} 


\section{Characteristics of congregation room}

The church in Gemersky Jablonec is the oldest in the micro region Medves, which is a valuable monument of the Romanesque architecture. There was a similar church in the neighbouring village Petrovce, which is already ruined. The churches have a similar disposition - longitudinal ship with quadrangular choir and a semicircular apse and a small tower on the western facade. Since the last century the church has moisture problems, despite the fact that it is on an elevated position [3].

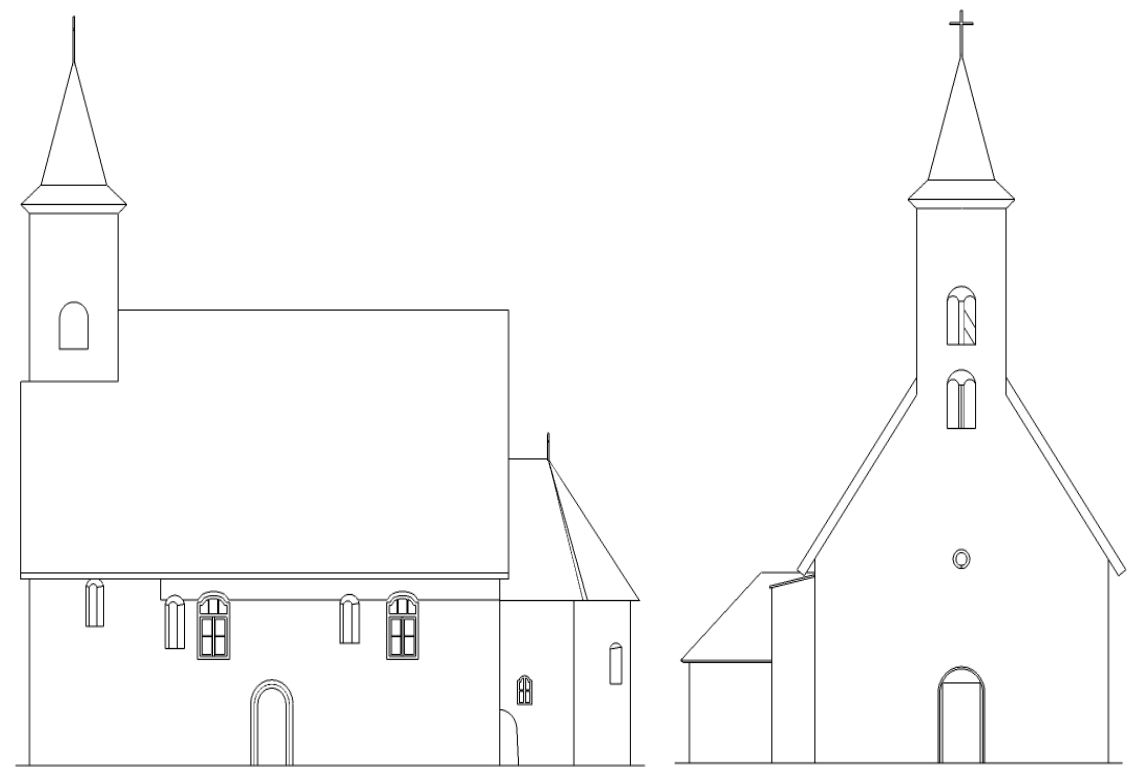

Fig. 1. The analyzed church in Gemer's Jablonec - Slovakia

Rys. 1. Analizowany kościół w Gemerskim Jabłońcu - Słowacja

In the construction of churches architects used different building materials. The already ruined church in Petrovce was built of bricks, while in Gemerský Jablonec just the foundation is made of bricks and above stone blocks were used. The walls were probably plastered [3].

Table 1. The number of persons in the church throughout week

Tabela 1. Liczba osób w kościele w ciągu tygodnia

\begin{tabular}{|c|c|c|c|c|c|c|c|}
\hline & Monday & Tuesday & Wednesday & Thursday & Friday & Saturday & Sunday \\
\hline Morning & 25 & 25 & 25 & 25 & 25 & 30 & 35 \\
\hline Lunch & 35 & 35 & 35 & 25 & 35 & 35 & 35 \\
\hline Evening & 15 & 15 & 15 & 25 & 15 & 25 & 20 \\
\hline
\end{tabular}


The total volume of air in the church is $400 \mathrm{~m}^{3}$ and total floor space is $140 \mathrm{~m}^{2}$. The windows are traditional wooden type with single glazing. The door are also wooden. The length of the joints for windows and door is $20 \mathrm{~m} \mathrm{[3]}$.

\section{Analise of ventilation in the room}

\subsection{Air exchange by infiltration}

The air exchange rate by infiltration is calculated for closed windows and door. The calculation [5] was performed from the next equation.

$$
\mathrm{n}=\frac{3600 \Sigma\left(\mathrm{i}_{\mathrm{V}} \cdot 1\right) \cdot \mathrm{E} \cdot \mathrm{M}}{\mathrm{V}_{\mathrm{b}}} \quad(1 / \mathrm{h})
$$

where: $i_{\text {lv }} \quad$ - coefficient of length of the joints air permeability $\left[\mathrm{m}^{2} /\left(\mathrm{s} \cdot \mathrm{Pa}^{0,67}\right)\right]$

1 - length of the joints [m]

B - characteristic of building number [-]

$\mathrm{M}$ - characteristic of room number [-]

$\mathrm{V}_{\mathrm{b}}$ - building volume $\left[\mathrm{m}^{3}\right]$

Calculated ventilation rate from the infiltration is $n=0,001 / h$ and $n=0,191 / h$.

\subsection{Determination of carbon dioxide mass flow}

During determining of mass flow of the carbon dioxide it is needed know production of carbon dioxide at person breathing. Composition of inhaled air is differing from composition of exhaled air. Exhaled air includes less oxygen, but more of carbon dioxide and water vapor $[1,2,4]$.

During the whole lifetime of a building it is required a permanent exchange of air between inside and outside the building, in order to control the indoor relative humidity of air. If the moisture is not removed adequate by means of ventilation, it will penetrate into the walls, which will create in time mold and dampness [7].

In our study it is calculated mass flow for every person in a room. A young person exhaled approximately $7.6 \mathrm{mg}$ of carbon dioxide per second, adult person exhaled approximately $10.15 \mathrm{mg}$ of carbon dioxide per second and elderly person exhaled approximately $12.2 \mathrm{mg}$ of carbon dioxide per second. The results are presented in Table 2. 
Table 2. The production of mass flow in the room

Tabela 2. Masa przepływu wytworzona w pomieszczeniu

\begin{tabular}{|c|c|c|c|}
\hline $\begin{array}{c}\text { Number } \\
\text { of persons } \\
{[-]}\end{array}$ & $\begin{array}{c}\text { Mass flow rate } \\
\text { of carbon dioxide } \\
{[\mathrm{mg} / \mathrm{s}]}\end{array}$ & $\begin{array}{c}\text { Needed } \\
\text { ventilation rate } \\
(\text { for } \mathrm{n}=0.001 / \mathrm{h}) \\
{[1 / \mathrm{h}]}\end{array}$ & $\begin{array}{c}\text { Needed } \\
\text { ventilation rate } \\
(\text { for } \mathrm{n}=0.191 / \mathrm{h}) \\
{[1 / \mathrm{h}]}\end{array}$ \\
\hline 15 & 159 & 1.33 & 1.20 \\
\hline 20 & 213 & 1.78 & 1.70 \\
\hline 25 & 266 & 2.22 & 2.20 \\
\hline 30 & 318 & 2.65 & 2.60 \\
\hline 35 & 377 & 3.14 & 3.20 \\
\hline
\end{tabular}

\subsection{Determination of needed ventilation rate}

By using the Equation (2) according to STN EN 13779 [6] we calculated the needed indoor air flow rate.

$$
\mathrm{q}_{\mathrm{v}}=\frac{q_{H}}{C_{I D A}-C_{S U P}}\left[\mathrm{~m}^{3} / \mathrm{s}\right]
$$

where: $\mathrm{q}_{\mathrm{V}}$ - air flow rate required for room ventilation, $\left[\mathrm{m}^{3} / \mathrm{s}\right]$,

$\mathrm{q}_{\mathrm{H}}$ - carbon dioxide emissions from the human source, $[\mathrm{g} / \mathrm{s}]$,

$\mathrm{C}_{\mathrm{IDA}}$ - carbon dioxide concentration in indoor air at time $\mathrm{t},\left[\mathrm{g} / \mathrm{m}^{3}\right]$,

$\mathrm{C}_{\text {SUP }}$ - carbon dioxide concentration in supply air at time $\mathrm{t},\left[\mathrm{g} / \mathrm{m}^{3}\right]$,

From the air flow rate it was calculated ventilation rate for a room. Results are documented in the Table 2.

\subsection{Determination of concentration of carbon dioxide}

The concentration over the value of $1,000 \mathrm{ppm}$ is unacceptable because the result generates discomfort caused by emissions released from the breathing of the occupants. In order to determine the required ventilation rate, it can be used the theoretical calculation method which determines the volumetric airflow rate. In this case, it is used the carbon dioxide concentration, as determined by experimental measurements. The measurements were carried out in the church, during the winter time. The carbon dioxide concentration in the room is calculated according the Equation (3) [3].

$$
\mathrm{C}_{\mathrm{IDA}}=\mathrm{C}_{\mathrm{SUP}}+\frac{\mathrm{q}_{\mathrm{H}}}{\mathrm{q}_{\mathrm{V}}} \cdot\left\{1-\exp \left[\left(\frac{-\mathrm{q}_{\mathrm{V}}}{\mathrm{V}_{\mathrm{M}}}\right) \cdot t\right]\right\}
$$

where: $\mathrm{C}_{\mathrm{IDA}}$ - carbon dioxide concentration in indoor air at time $\mathrm{t},\left[\mathrm{g} / \mathrm{m}^{3}\right]$,

$\mathrm{C}_{\text {SUP }} \quad$ - carbon dioxide concentration in supply air at time $\mathrm{t},\left[\mathrm{g} / \mathrm{m}^{3}\right]$,

$\mathrm{q}_{\mathrm{H}} \quad$ - carbon dioxide emissions from the human source, $[\mathrm{g} / \mathrm{s}]$, 
$\mathrm{q}_{\mathrm{V}} \quad$ - air flow rate required for room ventilation, $\left[\mathrm{m}^{3} / \mathrm{s}\right]$,

$\mathrm{V}_{\mathrm{M}} \quad$ - room volume, $\left[\mathrm{m}^{3}\right]$,

t - time, $[\mathrm{s}]$.

Results of the existing course of concentration of carbon dioxide that was calculated from experimental measurement are documented in the next figure.

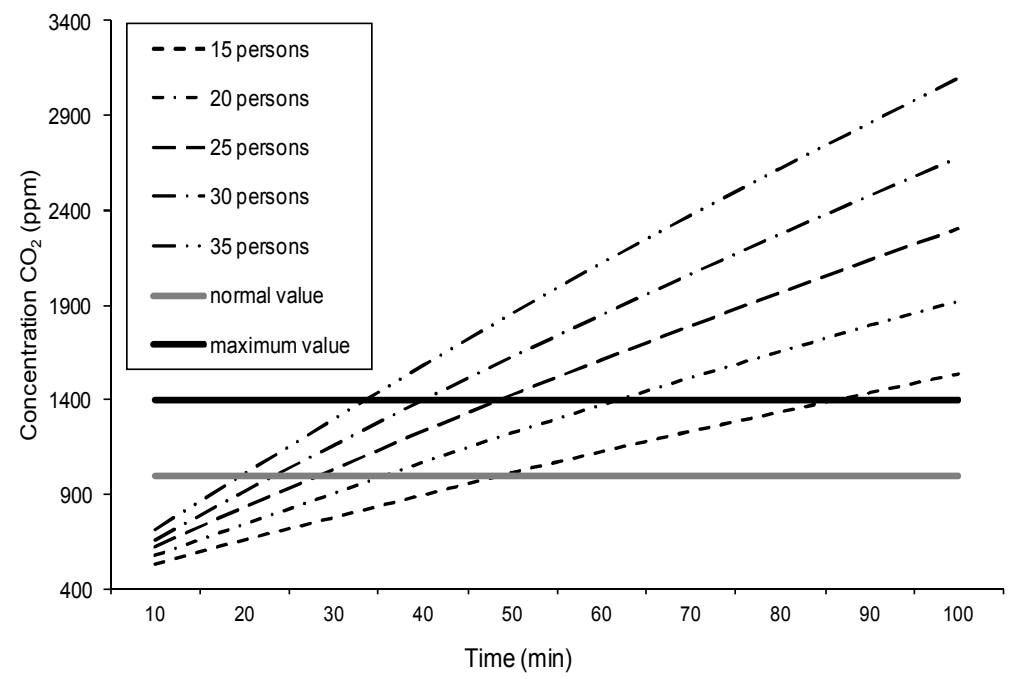

Fig. 2. The concentration of carbon dioxide

Rys. 2. Stężenie dwutlenku węgla

The calculated ventilation rate, based on the measured $\mathrm{CO}_{2}$ concentration, is from $n=0.191 / \mathrm{h}$ (room air volumes/h) to $n=3.201 / \mathrm{h}$ (room air volumes $/ \mathrm{h}$ ).

\section{Conclusion}

From analyze we see that old building - church was constructed very good. For a church, the calculated ventilation rate based on the measured of carbon dioxide concentration is more accurately than according the standard STN EN 13779 [6]. If there are only 10 people in the church there is no reason for mechanical ventilation. It is sufficient the ventilation by infiltration through the doors or windows gaps, even more as they are old. With the increasing of occupants inside the church it is necessity in more intensive ventilation - opening of door and windows.

\section{Acknowledgements}

This article was elaborated in the framework of the project KEGA 052 TUKE$4 / 2013$. 


\section{Bibliography}

[1] Budaiová Z., Vilcekova S. (2014) Impact of indoor environmental quality on users' performance in office - Case study. Quaere 2014. vol. 4, Hradec Králové, Czech Republic, ISBN 978-80-87952-04-7, p. 1418-1426;

[2] Edgar Voigt, Jens Pelikan: $\mathrm{CO}_{2}$-Measurement during Ventilation. Dräger Medizintechnik GmbH, Lübeck. ISBN 3-926762-38-1;

[3] Kapalo P., Sedláková A., Domnita F., Ťažký L.: Analyze of air exchange requirements in the spaces of church. In: SGEM 2015. Sofia: STEF92 Technology, 2015 P. 57-63. ISBN 978-619-7105-39-1 ISSN 1314-2704;

[4] Kridlova Burdova E., Vilcekova S.: Multi Criteria Analysis of the system environmentál assessements of buildings. In: TZB Haustechnik. (2010), ISSN 1210-356X, pp 38-40.

[5] STN EN 730540-2 (2012), Thermal performance of buildings and constructions, E.U., 2012, pp 3-8;

[6] STN EN 13779 (2007), Ventilation in nonresidential buildings. General requirements for ventilation and air conditioning equipment, E.U., 2017, pp 12-15;

[7] Toth S., Vojtuš J., Monitoring and analysis of fungal organisms in building structures, Advanced Materials Research, Vol. 969, Trans Tech Publications Inc., U.S.A., 2014, ISSN 1022-6680, pp 265-270.

\section{WYMOGI DLA ŚWIEŻEGO POWIETRZA WE WNETRZU KOŚCIOLA}

\section{Streszczenie}

Budowanych jest coraz więcej kościołów parafialnych. Wznosząc te obiekty należy przestrzegać wymogi dotyczące jakość powietrza wewnątrz nich. W artykule zajęto się analizą wentylacji w kościele z XIII wieku. Celem analizy była emisja zanieczyszczeń powodowana przez osoby będące w kościele. Jednym z mierzonych zanieczyszczeń był dwutlenek węgla wydychany przez osoby. Obok oddychania, osoba produkuje inne zanieczyszczenia, jak np. zapach. Na podstawie pomiarów doświadczalny poznano stężenie dwutlenku węgla wytwarzanego przez osobę, i jest znana konieczna objętość wymiany powietrza w kościele. Stężenie dwutlenku węgla powinna być mniejszym niż $1,000 \mathrm{ppm}$, a maksymalna do $1,500 \mathrm{ppm}$., ponieważ ponad wartością z 1,000 ppm skutkuje zmniejszenie koncentracji. Celem artykułu jest ustalenie metodologii dla obliczania intensywności wentylacji pomieszczenia, do uzyskania wymaganego stopnia czystości powietrza. Oszacowany wskaźnik wentylacji powinien optymalizować inwestycję i koszty eksploatacyjne wentylacji. Przedstawiono również analizę metod obliczania wskaźnika wentylacji dopasowanego do warunków obowiązujących na Słowacji.

Słowa kluczowe: wentylacja, stężenie dwutlenku węgla, współczynnik przepływu masowego kościół parafialny

Przestano do redakcji:8.06.2015

Przyjęto do druku:10.01.2016

DOI: $10.7862 / \mathrm{rb} .2015 .188$ 